\title{
需要家側の信頼度を考慮した相対契約 電力購入量決定の一手法
}

\author{
正員新岡 聡* 正員 横山 隆一**
}

\author{
An Electric Power Purchase Strategy for Bilateral Contracts \\ Focusing on Reliability of Customers \\ Satoru Niioka*, Member, Ryuichi Yokoyama**, Member
}

\begin{abstract}
With introducing the competitive electrical power market, large-scale customers can select electric power suppliers. Customers need to consider not only the economical efficiency but also reliability, to decide the amount of electrical power to purchase. This paper develops an economic electric power purchase strategy for customers focusing on reliability. A bilateral contract model expressing electric power suppliers as generators with a forced outage rate is proposed and introduced to assess potential outage risks of the bilateral contract between an electric power supplier and a customer. The outage-related cost, consisting of potential outage risks and the estimated outage cost, is also proposed and introduced as an index of the reliability on the customer side, and an optimal reliability level of a customer is obtained by using the index. Several numerical examples demonstrate the availability of the proposed electric power purchase decision method and reliability improvement strategies for customers are discussed.
\end{abstract}

キーワード：競争市場，相対契約，需要家

Keywords: competitive market, bilateral contract, customers

\section{1.はじめに}

電気事業への競争原理導入に伴って, 2000 年 3 月より 2 万 V・2000 kW 以上の特別高圧受電の需要家が供給事業者 を選択できるようになり，2004 年 4 月より $500 \mathrm{~kW}$ 以上の 高圧受電の需要家まで対象が広がることとなった。

競争原理導入前は, 規制下で地域独占供給を行ってきた 電力会社が供給信頼度を確保するための運用や設備増強計 画を進めてきたため, 供給支障の発生頻度や発生量は極め て小さく，需要家側での信頼度対策の必要性は比較的小さ かった。しかし，現在は送電設備投資額が減少し，ピーク であった 1993 年の半分程度になっている等, 供給信頼度 維持に繋がる積極的な設備増強は行われにくくなっており， 今後も同樣の状況が継続したときの, 設備不全による事故 の可能性が懸念されている。従って, 電力会社が従来に引

\footnotetext{
* (株) 三菱総合研究所 エネルギー政策研究部

干 100-8141 東京都千代田区大手町 2-3-6

Energy Policy Research Department, Mitsubishi Research Institute, Inc.

2-3-6, Otemachi, Chiyoda-ku, Tokyo 100-8141

** 東京都立大学大学院工学研究科電気工学専攻

干 192-0397 八王子市南大沢 1-1

Electrical Engineering Department, Tokyo Metropolitan University

1-1, Minami-osawa, Hachioji 192-0397
}

き続き電力の安定供給に責任をもつ供給主体として位置づ けられている現状においても,需要家は電力購入に際し, 経 済性のみならず信頼度維持対策も考慮する必要がある。

我が国に限らず，電力事業分野の自由化が進んでいる欧 米諸国においても信頼度を低下させてまでコストダウンを 図る動きはないものの, 自由化進展により信頼度が低下す ることへの懸念か指摘されている ${ }^{(1)}$ 。米国でも自由化後に 大規模な停電か発生するなど, 供給側はもちろんのこと, 需 要家側においても信頼度対策の重要性は増している。

需要家側で信頼度維持対策を行うためには，契約する供 給事業者を選択する際の信頼度評価手法と併せて, 信頼度 改善策の検討も必要となる。また, 信頼度の確保に経済メ カニズムが活用され，信頼度別供給 ${ }^{(1)(2)}$ のようなサービス か導入された場合などには, 費用対効果も含めた経济性と のバランスを考慮できる信頼度評価手法が必要となる。

経済性と信頼度維持は一般にトレードオフの関係にある ため，相対契約による電力購入量を決定する場合やオンサ イト電源を導入する場合の, 経済性と信頼度との適切な均 衡点の見極めは, 競争市場環境下におかれた需要家にとっ て非常に重要である。

電力系統の信頼度は供給側と需要家側に分けて考えるこ

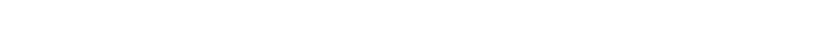
提案されている ${ }^{(3) \sim(8)}$ 。 
供給側においては, 潜在的な停電リスクか議論されるこ とが多いため, 確率的な手法に基ついた信頼度評価指標が 用いられてきた。中でも，供給支障電力量の期待值を用い

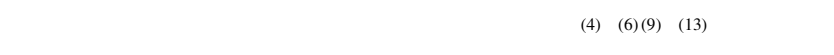
側においては，顕在化したリスク，すなわち停電をもとに 信頼度を評価するため, 定量的な信頼度指標が用いられる ことが多い(3)(7)(8)。

確率的な評価手法は, 流通設備分野や需要家の接続点で の信頼度評価など，これまで定量的な評価手法が多く使わ れてきた分野への適用か試みられており，供給信頼度を定 量的に評価することでコストと信頼度の関係を明確にする 提案がなされている(1)(6)(9) (13)。確率的手法, 定量的手法の 弚れ光れに長所があるが，これまでに提案されてきた信頼 度評価手法はいずれか一方の手法により評価を行っている。 しかし, 需要家の負荷構成に関わる特性が異なれば，兴の 信頼度評価に使用すべき手法が異なる可能性は高い。

乥こで本論文では, 需要家が, 特性に応じて適宜確率的 手法と定量的手法を選択して信頼度評価を行い，相対契約 による電力購入量を決定する手法を提案する。まず第 2 章 において，供給事業者発電設備や流通設備の事故に起因す る潜在的な停電リスクを評価するための相対契約モデルに ついて述べる。続いて第 3 章では，想定事故による損害見 積と潜在的な停電リスクから計算される停電に関わるコス 卜を信頼度評価指標として提案し, 需要家の特性を反映し た信頼度評価手法について述べる。光して第 4 章では, 需 要家側で行う信頼度向上策と光の費用対効果の評価につい て述べる。第 5 章では, テスト系統を使用した数値計算例 により，提案手法が需要家の電力購入量決定に有効である ことを検証する。最後に第 6 章において，まとめと今後の 課題について述べる。

\section{2. 停電リスクを考慮した相対契約}

〈2 1〉相対契約モデル 需要家と相対契約を結んだ供 給事業者は, 流通設備を通して電力を供給している。需要 家が受け取る電力は供給事業者の発電規模に依存しないた め，需要家側から見た供給事業者は，ある事故率 FOR を 持った, 契約電力と同容量の発電機が, 流通設備を通して 電力を供給していると考えることができる (図 1)。

本論文では, 相対契約先供給事業者を契約電力と等容量

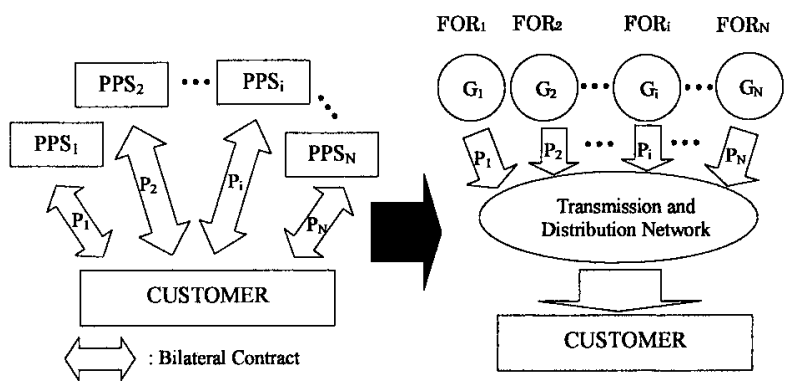

図 1 相対契約モデル

Fig. 1. Bilateral contract model.
の発電機に置き換えた，需要家側からみた相対契約モデル を導入し，供給事業者の発電機事故および流通設備事故に よる供給支障を計算し，需要家側の信頼度を評価すること を提案する。

〈2 2〉 流通設備事故の取り扱い 流通設備事故の信頼 度への影響は, 次のように取り扱う。

最初に $\mathrm{k}$ 本の送電線あるいは配電線事故が発生した場合 に, 需要家から供給事業者までの送電ルートが存在するか 否かを判定する。ルートが存在しない場合には，供給事業 者, すなわち導入した相対契約モデルにおける等価的な発 電機を事故による供給停止状態とし，等価的な発電機の事 故率 FOR を(供給事業者の発電設備事故率+流通設備 $\mathrm{k}$ 本 事故発生確率) に更新する。1つでもルートが存在した場 合には更新しない。例えば送電線の N-1 基準を適用した場 合, 送電線 $\mathrm{i}$ の事故により，需要家接続ノードから供給事業 者接続ノードへ至る送電ルートが途絶えたとすれば，FOR は (供給事業者発電設備事故率 + 送電線 $\mathrm{i}$ の事故率) とな る。需要家と供給事業者間の送電ルートが存在する場合に は，FOR は供給事業者発電設備の事故率のみを用いる。

このようにして流通設備事故による影響を等価的な発電 機の事故率 FOR に組み込むことにより，流通設備も考慮 した信頼度評価が可能となる。送電ルートの探索方法は次 節に示す。

〈2 3 $\rangle$ 送電ルートの探索 流通設備事故時の需要家と 供給事業者間の送電ルートの有無を探索するために，本論 文では文献 (14)の中で紹介されている接続遷移行列を使用 する。接続遷移行列を使用して需要家と供給事業者間の経 路探索を行うために, 以下の規則に従って, 送電線および 配電線を有向グラフに置き換える。

（1）需要家か接続するノードにおける有向グラフは,す べて需要家が接続するノードを始点とする。

（2）目的ノード（供給事業者接続ノード）における有 向グラフは，すべて目的ノードを終点とする。

(3) 需要家接続ノードと目的ノード以外のノードは, 必 ず1つ以上の始点および終点を含む。

有向グラフからインシデント行列を作成し，更に接続遷 移行列を作成すると, 需要家か接続するノードから目的ノー ドに至る送電ルートの有無を判断できる。

\section{3. 需要家側での信頼度評価}

〈3. 1〉需要家の電力調達 競争市場環境下の電力調達 方法は, プール型市場からの購入と供給事業者との相対契 約による購入の 2 種類に大別される。また , 負荷の一部ま たは全部をオンサイト電源導入による自前の電力供給でま かなうという選択肢も需要家にはある。本論文では, 需要 家の電力調達方法として, 相対契約購入およびオンサイト 電源導入を選択肢とする場合についての検討を行う。

本論文では, 需要家および供給事業者の行動等について， 以下の前提条件のもとに検討を進める。

(1) 需要家の提案手法による電力調達検討時期は, 短 
期の電力購入計画を立てる段階とする。また，信頼度レベ ルや電力購入費用によって調達量を変化させないとする。

(2) 需要家は 1 日を 8 時間ごとの 3 つの時間帯に分割 し，時間帯ごとに電力購入量を決定することとする。

（3）需要家は，供給事業者や流通設備の事故率に関す るデータを, 供給事業者等から提示を受ける，あるいはこ れまでの実績から類推するなどして入手可能とする。

（4）供給事業者の販売電力価格曲線は購入量によって 変化しないものとし, 電力の販売量については, 実際に購 入交渉を行う際，他の需要家との契約状況によって供給事 業者から希望量の電力を購入できない可能性も考慮した検 討を行うものとする。

（５）信頼度対策や停電対策等の選択肢の一つとして, 需 要家はオンサイト電源の導入が可能とする。

（6）電力購入先と電力購入量の決定プロセスは，供給 事業者が電力価格および販売可能電力の上限を提示の後, 需要家が希望する電力購入量を提示するという順番で意志 決定が行われることとし，電力価格の高低によって販売量 上限を変えるなどの交渉は行われないものとする。

（7）需要家は, 契約先の発電事業者からの供給が受け られない場合に負荷遮断を行うものとする。

〈3. 2〉 信頼度評価指標の設定需要家が, 信頼度を考 慮して電力購入量を決定するためには, 需要家にとって適 切な信頼度レベルを見極める必要がある。一般に，電力系 統の計画段階では,供給信頼度と供給コストとの間には, レードオフの関係があるため，供給信頼度指標として停電 コストを用いて，供給コストと停電コストの和である社会 コストが最小となる点を最も望ましい信頼度レベルとする

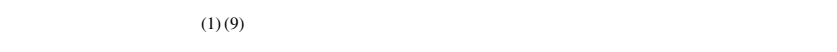
性と信頼度に着目した購入量決定は，系統運用者による供 給信頼度を考慮した経済的な発電機出力配分決定とほぼ等 価と捉えられる。従って，需要家の停電コストを信頼度指 標とし, 電気料金と停電コストの和を需要家側での電力コ ストとすれば，電カコストが最小となるとき，信頼度レベ ルが適切であると考えることができる。

本論文では,需要家の停電コスト評価に当たり，想定事故 による損害見積だけでなく，供給事業者の発電機事故率等 から計算される潜在的な停電リスクも併せて考慮した「停 電に関わるコスト」を定義し，これを需要家における信頼度 評価指標として需要家の特性を反映した信頼度評価を行う。

(1) 式のように,需要家側での電カコスト $E C$ を注目する 期間における，購入する電気料金 $E P$ と停電に関わるコス ト OCの和として定義すると，

$$
E C=E P+O C
$$

電カコスト $E C$ を最小とする点が需要家側での最適な信 頼度レベルと考えることができる (図 2)。

供給事業者が提示する電気料金 $E P$ は，発電のための燃 料費 $V C$, 設備の減価償却等の固定費 $F C$, 託送費用 $W C$, 事業者の利益 $P R O F$ の和となる。従って，

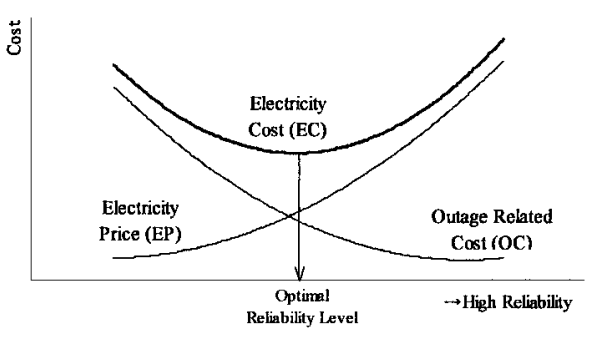

図 2 最適な信頼度レベル

Fig. 2. Optimal reliability level.

$$
E P=V C+F C+W C+P R O F
$$

と表すことができる。

一般に, 電力購入量を決定する場合, 想定される事故状 況下で発生する供給支障に対する損害を小さくするような 電力調達か望ましいが, 需要家の負荷構成が重要負荷の占 める割合が高い上に負荷同士が同期運用されている場合な ど, わずかな供給支障量でも影響が波及し, 全ての負荷に 供給支障が発生した時に相当する損害が予想されるような 場合には, 供給事業者からの電力購入量を変化させても想 定事故下での損害を低減できない可能性がある。このよう な場合の信頼度向上策としては, 事故発生確率が低い供給 事業者からより多くの電力を購入し，潜在的な停電リスク を低減するような電力調達が適していると考えられる。

本論文では，需要家の供給支障に対する損害特性を電力 購入量決定に反映できるように, 潜在的な停電リスクを表 す停電コス卜期待値 ExCOST と，想定事故による損害見積 であるAcCOST に重みをつけたものの和を，信頼度評価指 標である停電に関わるコスト $O C$ として提案する。潜在的

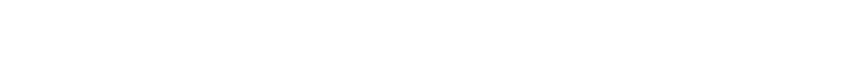
る重み係数を $g$ と $h$ とすると, 停電に関するコストは

$$
O C=g * E x \operatorname{COS} T+h * A c \operatorname{COS} T
$$

ただし，潜在的な停電リスク評価には，想定事故と同条 件の事故も含まれているため, $O C$ 算出に影響が重複して 算入されないよう，重み係数である $g$ および $h$ は以下の条 件を満たすこととする。

$$
g=0, h \neq 0, \text { あるいは, } g \neq 0, h=0
$$

潜在的な停電リスクと，想定事故による損害見積のいず れかを用いた評価によって，需要家の負荷特性に合った信 頼度評価が可能となる。更に，信頼度が向上すれば $O C$ の 值は小さくなり，悪化すれば $O C$ の値は大きくなるため，需 要家は $O C$ の値を通して信頼度向上策の効果を把握できる。

次節以降に ExCOST およびAcCOST の算出方法並びに 重み係数の設定方法について述べる。

〈3.3〉需要家の停電に関わるコスト＼cjkstart停電に関わるコ ストを算出するために，潜在的な停電リスク ExCOST と想 定事故による損害見積 AcCOST を計算する。

潜在的な停電リスク ExCOST は, 以下のように求められ 


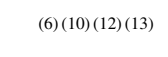

発電機や送電線等，設備 $j$ の事故率を FOR $j$,設備 $j$ の 事故によって影響を受ける需要家の負荷量 (遮断される負 荷量）を $C L_{j}, 1 \mathrm{~kW}$ 当たりの停電コストを $C D_{j}$ とすると， 設備 $j$ の事故により供給不足となる電力に対して，需要家 の停電コストの期待値 $\operatorname{ExCOS} T_{j}$ は

$$
\operatorname{ExCOS} T_{j}=C L_{j} * C D_{j} * F O R_{j}
$$

$1 \mathrm{~kW}$ 当たりの停電コスト $\mathrm{CD}_{j}$ は, 停電継続時間によっ て異なる。従って，CD $D_{j}$ は，停電継続時間の関数となるた め, 設備 $j$ の平均の回復時間 (平均の事故継続時間) を $r_{j}$ と し, 停電損害関数 (文献 (10) 等における Customer Damage Function に相当) を $f\left(r_{j}\right)$ とすれば，(4) 式は

$$
E x C O S T_{j}=C L_{j} * f\left(r_{j}\right) * F O R_{j}
$$

需要家への電力供給に関わる全ての設備に関して , 兴の 合計が潜在的な停電リスク $\operatorname{ExCOST}$ となる。

$$
\operatorname{ExCOST}=\sum_{j=1}^{N} \operatorname{ExCOS} T_{j}
$$

想定事故による損害見積である $A c C O S T$ は次のように して計算される。

需要家が $N$ 台の発電機 ( $N$ 社の供給事業者) と契約して いる時, 契約電力が大きい順に $1,2, \cdots, N$ と番号を付け れば，発電機事故により発生する供給支障の最大值は，

1 台事故の場合 : $G_{1}$

2 台事故の場合 : $G_{1}+G_{2}$

$i$ 台事故の場合 : $\sum_{j=1}^{i} G_{j}$

$N$ 台事故の場合 : $\sum_{j=1}^{N} G_{j}(=D)$

と表現することができる。ここで,$i$ 台事故時の停電コスト の最大值を AcCOSTi とすると，以下の関係が成り立つ。

$$
\operatorname{AcCOS} T_{1}<\operatorname{AcCOS} T_{2}<\cdots<\operatorname{AcCOS} T_{i}<\cdots<\operatorname{AcCOS} T_{N}
$$

$A c C O S T i$ は, $i$ 台事故継続時間 $r_{i}$ に対する停電損害関数 を用いて，

$$
\operatorname{AcCOS} T_{i}=\sum_{j=1}^{i} G_{j} * f\left(r_{i}\right)
$$

となる。 $m$ 台多重事故に対して, 重み係数 $h_{m}$ を用意し

$$
h * A c \operatorname{COS} T=h_{m} * A c \operatorname{COS} T_{m}
$$

とすれば，重み係数 $h_{m}$ を決定することによって， $m$ 台の 発電機事故を想定した (3) 式第 2 項が求められる。
〈3. 4 〉 停電損害関数 発電機の事故等によって発生す る供給支障電力に対しての損害額 $D M$ は, 重要負荷以外の 負荷遮断量が供給支障電力を上回っている場合は比較的小 さい状態で推移し, 重要負荷を遮断する必要が生じた場合 に急激に増大すると予想されるため,以下のように Sigmoid 関数で近似が可能な変化をするものと考えられる。

$$
D M\left(C L_{i}, r\right)=\frac{D M \max (r)}{1+e^{a *\left(z-C L_{i} / D\right)}}
$$

ここで, $D M \max$ は事故継続時間が $r$ の場合の $1 \mathrm{~kW}$ あ たりの停電コスト最大値, $a$ はSigmoid 関数の立ち上がり の傾き， $C L_{i}$ は停電による供給支障， $D$ は全負荷量， $z$ は 重要負荷を除いた負荷の割合であり，図 3 における 100-Xi に相当する。

(10) 式で表される供給支障電力一停電コスト曲線は, 負荷 構成が同じ場合でも，停電の継続時間によって変化する。(5) 式における停電の継続時間 $r_{j}$ に対応した供給支障電力一停電 コスト曲線を用いると，負荷遮断量 $C L_{j}$ に対応する停電コ ストが定まり，(4) 式における $C D_{j}$ を求めることができる。

アンケート調査による停電コストを記述している文献 (10) や文献 (15) の結果から，停電の継続時間に対する $1 \mathrm{~kW}$ あ たりの停電コスト最大値は停電発生直後がもっとも高く， 停電継続時間が長くなるに従い小さくなっていることがわ かる。文献 (10)や文献 (15) では変化の樣子のグラフは示さ れていないが, $1 \mathrm{~kW}$ あたりの損害額をプロットすると，時 間の経過とともに小さくなるので，本論文では $1 \mathrm{~kW}$ あた りの停電コス卜最大值 $D M \max (r)$ を, 図 4 のような指数 関数で近似する。

事故が発生した発電機が，時間 $r$ の間供給を停止してい るとすると， $1 \mathrm{~kW}$ あたりの停電コスト最大値 $D M \max$ は

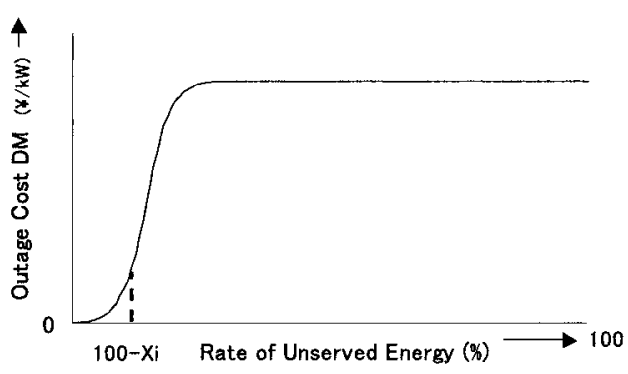

图 3 供給支障電力と停電コスト

Fig. 3. Outage cost for unserved power.

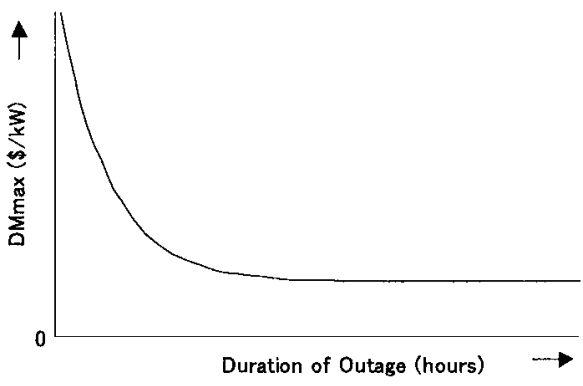

図 $41 \mathrm{~kW}$ あたりの停電コスト最大値

Fig. 4. Maximum outage cost per $1 \mathrm{~kW}$. 
$D M \max (r)=O C c s t * A^{-k\left(r-T_{C}\right)}$

ここで,

OC c st : 停電コスト係数
$A$ :指数関数の底
$k$ : 停電コス卜減衰係数
$T_{C}: 1 \mathrm{~kW}$ あたりの停電コストがほぼ一定となるま でに要する時間

であり，停電コスト係数は，時間 $T c$ 経過後の $1 \mathrm{~kW}$ あたり の停電コストとなるよう定める。停電コス卜減衰係数は， $D M$ max が, 想定する最も短い停電継続時間に対する $1 \mathrm{~kW}$ あたりの停電コストとなるように定める。ある負荷遮断量 $C L$ に対し，(10) 式の $D M \max$ を用いると，停電損害関数 $f(r)$ は

$$
f(r)=D M(C L, r)
$$

本論文では, 文献 (10) および文献 (15) の報告結果を参考 にして停電損害関数を決定する。

〈3. 5〉 重み係数の決定全需要に占める重要負荷の 割合が高い需要家で，(9) 式の $a$ の值が大きく，zの值が小 さな需要家は, 潜在的な停電リスクを低減するように電力 を購入することか効果的であると考えられる。潜在的な停 電リスクを低減するためには, ExCOST が小さくなるよう に電力購入量を決定する。これは, 事故率の低い発電機か ら多くの電力を購入する方向へ $E C$ の最適点を誘導する。 従って , (3) 式の重み係数 $g$ を非ゼロ , $h$ を 0 とすることに より特性を反映できる。逆に，一部の負荷遮断により，想 定事故による損害が低減できる場合には , $i$ 台の想定事故に よる損害見積 $A c C O S T$ が小さくなるように電力購入量を 決定することか効果的であると考えられる。これは，各発 電機からの電力購入量が等しくなる方向へ $E C$ の最適点を 誘導する。この場合には, 重み係数 $g$ を $0, h$ を非ゼロとす ることにより特性を反映できる。

需要家特性を反映した重み係数設定手順を以下に示す。

（1）負荷を停電時の損害が比較的小さいもの)(非重要 負荷) と，大きいもの (重要負荷) に分類する。

（2）重要負荷を遮断した場合の停電損害額の上昇具合 ((11) 式 $D M$ における $a$ の值) を求める。

(3) $1 \mathrm{~kW}$ あたりの停電コス卜最大值 $D M \max$ を求 める。

（4）停電コス卜を考慮しない, 最も経済的な各供給事 業者からの電力購入量を求める ( $E P$ の最小化)。

( 5 ) $E P$ 最小化時の電力購入量に対して, 基準とする停 電 (例えば発電機の 1 台事故による停電) が発生した場合 に重要負荷の遮断が必要かどうかを判定する。

（6）重要負荷の遮断が必要な場合は(8)へ, 非重要負 荷の遮断のみで斉む場合は $(7)$ へ進む。

（7）想定する $i$ 台の発電機事故に対する重み $h_{i}$ を設定 する。重み係数 $g$ を含む他の重み係数は 0 とする。想定事 故による損害に対する考え方次第で,$h_{i}$ 設定方法は多数存 在するが, 本論文では, $i$ 台事故発生時における供給支障量

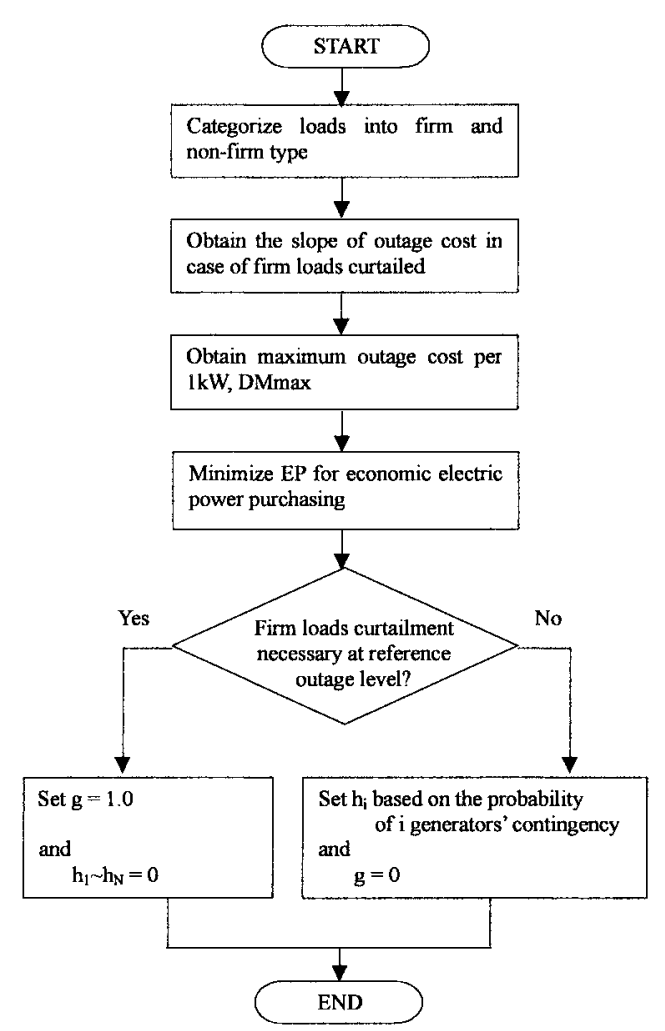

図 5 重み係数決定手順

Fig. 5. Weighting coefficient setting procedure.

と各発電機の事故率から計算される供給支障量期待值の比 を $i$ 台事故発生確率に乗じた值を採用した。

(8) $h_{1} \sim h_{N}$ を 0 とし，非ゼロの $g$ を設定する。 $\operatorname{ExCOST}$ は発電機事故率に基づいた期待值であるため, 本 論文では $g=1.0$ を妥当な数値であると考え，この值を採 用する。

図 5 に重み係数設定手順フローチャートを示す。

4. 需要家側での信頼度向上策

〈4 1〉 経済性のみを考慮した電力調達需要家が, 信 頼度を考慮せず，電気料金 $E P$ を最小とするように，電力購 入量を決定した場合，電力購入量べクトルを $x_{e}$ とすると，

$\min \operatorname{EP}\left(x_{e}\right)$

subject to

$\sum_{i} G_{i}\left(x_{i}\right)=D$

$G_{i} \leq G_{i \max }$

を満たす $x_{e}$ が電力購入量となる。上式の $x_{e}$ に対して, 信 頼度向上の選択肢は次のものが考えられる。

（1）配電線などの流通設備増強

(2) 調達先の電力購入量変更

(3) 自家発電設備等オンサイト電源の導入

上記の選択肢について, 需要家が取りうる行動について 検討する。

〈4 2〉配電線などの流通設備増強 流通設備の増強 
は, 潜在的な停電リスクの低減に大きな効果か期待できる が，一需要家だけで決定できる性質の選択肢でなく，周辺 の他の需要家や流通設備所有者との協議が必要と考えられ るため, 需要家が取りうる行動が基本的にはないものとみ なし，本論文では選択肢から除外する。

〈4３〉調達先の電力購入量変更（13）式で決定された $x_{e}$ に対して, 電力購入量を変更することで信頼度か湾化す る。(13) 式において, 購入電気料金 $E P$ の代わりに目的関 数を(1) 式の電力コスト $E C$ とし,$E C$ を最小化する電力購 入ベクトル $\boldsymbol{x}$ を求めることによって，信頼度を考慮した電 力購入量が決定可能となる。

供給事業者の販売量上限次第では, 電気を希望通り購入 できない可能性がある。弚の場合に需要家がとる行動とし ては, 希望購入量に近い量を購入し, 光れ以上の信頼度向 上策は行わないか，あるいは次節で述べるオンサイト電源 導入を行うかのいずれかであると考えられる。

〈 4 4 オンサイト電源の導入 オンサイト電源を導入 した場合も，EC等の計算方法は基本的には前節の場合と 同樣であるが，オンサイト電源は流通設備事故の影響を受 けないため，送電ルート探索による FOR の修正は必要な い。また，減価償却費用か嫦に発生する。これらの点に関 わる修正を行い， $E C$ を最小化する電力購入ベクトル $x$ を 計算し電力購入量を決定する。

$\langle 4$ 5 $\quad$ 信頼度向上策の評価 $\langle 4 \cdot 3\rangle$ および $\langle 4 \cdot 4\rangle$ 節で 記述した信頼度向上策実効前の各値に添え字 $B$ を，信頼度 向上策実行後の各值に添え字 $N$ を付けて表し, 信頼度向上 策実行前後を比較することによって，信頼度を考慮したこ とにより回避された停電の損害について評価する。

信頼度向上策を実行した結果として, 以下の 3 種類の状 況が考えられる。

$$
\begin{aligned}
& O C_{B}>O C_{N} \text { かつ } E C_{B}<E C_{N} \\
& O C_{B}>O C_{N} \text { かつ } E C_{B}=E C_{N} \\
& O C_{B}>O C_{N} \text { かつ } E C_{B}>E C_{N}
\end{aligned}
$$

$(16)$ 式および $(17)$ 式の場合には, $E P_{N}$ が $E P_{B}$ より大きく なり，経済性を代償として停電による損害を回避している。 (18) 式の場合には, $E P_{N}$ と $E P_{B}$ との差は非常に小さいと 考えられ，経済性をあまり低下させることなく信頼度を向 上できたこととなり，最も効果的な対策であるといえる。

信頼度向上対策の費用対効果は，回避された損害額と実 際の電気料金増分との対比に関する議論が必要となるが， $O C$ と $E P$ の変化を比較することによって評価可能である。

\section{5. 数值計算例}

〈5 1〉送電系統の構成 图 6 に検証に使用するテス 卜系統の構成を示す。テスト系統は, IEEE RELIABILITY TEST SYSTEM (RTS-96) ${ }^{(1)}$ に修正を加えたものを使用し た。シミュレーションにおいては，供給事業者が接続する 発電機ノードを 5 ノード, 需要家が接続可能な負荷ノード を2ノード想定した。各ノードを慗ぐ送電線の事故率と平

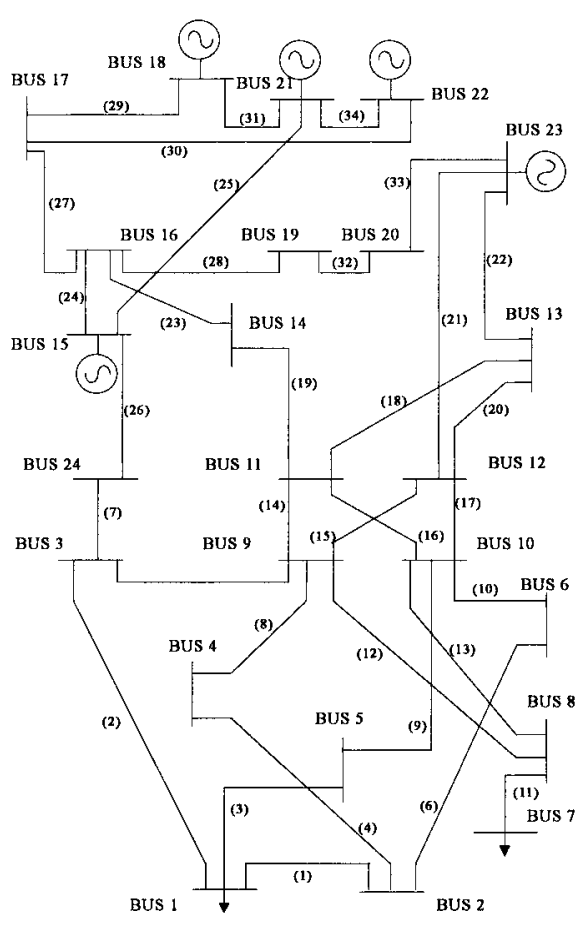

図 6 テスト系統 (IEEE RTS96 を修正)

Fig. 6. Test system (modified IEEE RTS96).

表 1 送電線特性

Table 1. Characteristic of transmission line.

\begin{tabular}{|c|c|c|c|c|c|}
\hline No & $\begin{array}{c}\text { Outage } \\
\text { Rate (\%) }\end{array}$ & $\begin{array}{c}\text { Outage } \\
\text { Duration (Hrs) }\end{array}$ & No & $\begin{array}{c}\text { Outage } \\
\text { Rate (\%) }\end{array}$ & $\begin{array}{c}\text { Outage } \\
\text { Duration (Hrs) }\end{array}$ \\
\hline 1 & 0.24 & 16 & 18 & 0.40 & 11 \\
\hline 2 & 0.51 & 10 & 19 & 0.39 & 11 \\
\hline 3 & 0.33 & 10 & 20 & 0.40 & 11 \\
\hline 4 & 0.39 & 10 & 21 & 0.52 & 11 \\
\hline 5 & 0.48 & 10 & 22 & 0.49 & 11 \\
\hline 6 & 0.38 & 10 & 23 & 0.38 & 11 \\
\hline 7 & 0.38 & 10 & 24 & 0.33 & 11 \\
\hline 8 & 0.36 & 10 & 25 & 0.41 & 11 \\
\hline 9 & 0.34 & 10 & 26 & 0.41 & 11 \\
\hline 10 & 0.33 & 10 & 27 & 0.35 & 11 \\
\hline 11 & 0.30 & 10 & 28 & 0.34 & 11 \\
\hline 12 & 0.44 & 10 & 29 & 0.32 & 11 \\
\hline 13 & 0.44 & 10 & 30 & 0.54 & 11 \\
\hline 14 & 0.38 & 10 & 31 & 0.38 & 11 \\
\hline 15 & 0.38 & 10 & 32 & 0.38 & 11 \\
\hline 16 & 0.38 & 10 & 33 & 0.34 & 11 \\
\hline 17 & 0.38 & 10 & 34 & 0.45 & 11 \\
\hline
\end{tabular}

均の事故継続時間を表 1 に示す。

〈5. 2〉 供給事業者の特性 供給事業者は 1 時間単位で の電力販売価格を提示するものとする。また，本論文で採 用する電気料金モデルにおいては, 供給事業者の発電機は 火力機を想定し，固定費 $\mathrm{FC}$, 託送費用 $W C$, 利益 $P R O F$ の $1 \mathrm{~kW}$ 当たりの值が電力販売量に関わらず一定とした。こ のとき, $x(\mathrm{~kW})$ で $\mathrm{T}$ 時間の電力購入時の電気料金 $E P$ は

$$
E P=\left\{a x^{2}+(b+d+e+f) x+c\right\} \cdot T
$$

で与えられる。ただし
$\mathrm{a}:$ 燃料費の 2 次項係数
$\mathrm{b}:$ 燃料費の 1 次項係数
$\mathrm{c}:$ 燃料費の定数項係数 
$\mathrm{d}:$ 固定費 $F C$ の償却に関わる係数

$\mathrm{e}:$ 託送費用 $W C$ に関わる係数

$\mathrm{f}:$ 利益係数

である。

表 2 に各供給事業者の電気料金データと事故率を，表 3 に各供給事業者の販売電力上下限を光れ光れ示す。供給事 業者の事故率の信頼度への影響をより顕著にするため，各 供給事業者間の事故率の差が大きめになるように事故率を 設定し, 事故率の高い供給事業者ほど販売電力上下限が高 くなるように上下限を設定した。

〈5 3〉配電系統の特性配電系統は, 1 回線の放射状 系統とし，構造を図 7 に,事故率と事故継続時間は表 4 に示 す。事故率等のデータは文献 (17) を参考として設定した。

本論文では, 配電系統における変圧器および変電所の事 故は考慮しないこととする。

〈5. 4 〉 需要家の特性 需要家は図 6 における第 1 ノー ドおよび第 7 ノードのいずれかで接続し，高圧で受電する ものとする。需要家の負荷構成は, 重要負荷の割合が高い 場合と低い場合の 2 種類を仮定し，時間帯ごとにいずれか の特徵を有することとした。需要家の全負荷量と重要負荷

\section{表 2 供給事業者の電気料金と事故率}

Table 2. Electricity price and FOR of electric power suppliers.

\begin{tabular}{|c|c|c|c|c|c|c|c|c|}
\hline No & $\mathrm{a}$ & $\mathrm{b}$ & $\mathrm{c}$ & $\begin{array}{c}\mathrm{d} \\
(¥ / \mathrm{kW})\end{array}$ & $\begin{array}{c}\mathrm{e} \\
(¥ / \mathrm{kW})\end{array}$ & $\begin{array}{c}\mathrm{f} \\
(¥ / \mathrm{kW})\end{array}$ & $\begin{array}{c}\text { FOR } \\
(\%)\end{array}$ & Bus \\
\hline 1 & 0.030 & 2.0 & 350 & 1.0 & 4.0 & 0.40 & 0.5 & 15 \\
\hline 2 & 0.018 & 2.2 & 400 & 1.0 & 4.0 & 0.39 & 0.7 & 18 \\
\hline 3 & 0.014 & 2.5 & 450 & 1.0 & 4.0 & 0.37 & 1.0 & 21 \\
\hline 4 & 0.009 & 3.2 & 500 & 0.8 & 4.0 & 0.34 & 2.0 & 22 \\
\hline 5 & 0.007 & 3.6 & 500 & 0.8 & 4.0 & 0.32 & 3.0 & 23 \\
\hline
\end{tabular}

表 3 供給事業者の販売電力上下限

Table 3. Upper and lower limit of PPS's supply.

\begin{tabular}{|c|c|c|c|c|c|}
\hline No & 1 & 2 & 3 & 4 & 5 \\
\hline Upper Limit (kW) & 250 & 300 & 350 & 600 & 600 \\
\hline Lower Limit (kW) & 50 & 50 & 100 & 100 & 150 \\
\hline
\end{tabular}

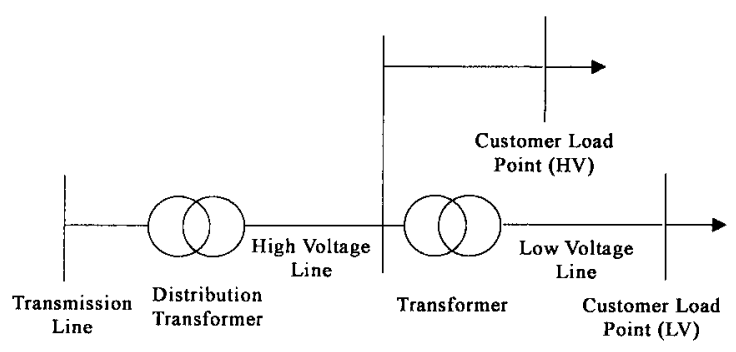

図 7 配電系統構造

Fig. 7. Structure of distribution system.

\section{表 4 配電系統の事故特性}

Table 4. Characteristics of distribution system failure.

\begin{tabular}{|c|c|c|}
\hline & Failure Rate (\%) & Repair Time (hrs) \\
\hline High Voltage Line & 4.6 & 4 \\
\hline Low Voltage Line & 6.5 & 2 \\
\hline
\end{tabular}

量を表 5 に示す。需要家の全負荷および重要負荷は各時間 帯において変化せず,一定容量とした。また, 重要負荷の 容量はすべての時間帯で同じとしたため, 全体の負荷量が 小さい場合には負荷全体に占める重要負荷の割合が高くな り，全体の負荷量が大きい場合には午の割合は低くなる。

表 5 より，供給支障電力に対しての損害額 DM を決定す るための (10) 式の係数は表 6 に $D M \max$ を求めるための (11) 式の係数を表 7 に示す。各值は文献 (10) における工業 需要家のケースを参考として決定した。

停電継続時間については, 3 分割した各時間帯において， いずれの発電機事故においても, 継続時間 $r$ は 4 時間とし た。また, sigmoid 関数の傾き $a$ は $z$ に反比例するものと し，500/zの值を採用した。

表 6 および表 7 の係数を用いると，停電損害関数 $\mathrm{f}$ の最 高値は約 $5900(¥ / \mathrm{kW})$ となる。

停電に関するコスト $O C$ の重み係数を表 8 に示す。発 電機の 1 台事故想定下で重要負荷の遮断が必要な場合には $E x \operatorname{COS} T$ の重み係数 $g$ を $1.0, A c C O S T$ の重み係数 $h$ を全 て 0 とする。重要負荷の遮断が必要ない場合には $g$ を $0, h$ については発電機の 2 台事故を考慮することとし , $\langle 3 \cdot 5\rangle$ 節 （7）に基づき以下のように決定した。

表 2 における 5 つの供給事業者の中で任意の 2 社で事故が 発生する確率は $0.18 \%$ である。また, 軽負荷時 $(1000 \mathrm{~kW})$ において, 各供給事業者から同量の電力を購入していると 仮定すると，供給支障量期待値は

$$
200 *(0.05+0.07+0.01+0.02+0.03)=14.4 \mathrm{~kW}
$$

である。事故発生による実際の供給支障量は $400 \mathrm{~kW}$ であ り，期待值に対して約 27.8 倍の規模である。従って，

$$
0.0018 * 27.8=0.05004
$$

表 5 需要家の全負荷量と重要負荷量

Table 5. Customer's total load and firm load.

\begin{tabular}{|c|c|c|c|}
\hline Time-of-day & $0-8$ & $9-16$ & $17-24$ \\
\hline Total Load (kW) & 1000 & 1500 & 1000 \\
\hline Firm Load $(\mathrm{kW})$ & 900 & 900 & 900 \\
\hline
\end{tabular}

表 6 DM の係数

Table 6. Coefficients for DM.

\begin{tabular}{|c|c|c|c|}
\hline & $\mathrm{r}$ (hours) & $\mathrm{z}(\%)$ & $\mathrm{a}$ \\
\hline Light Load & 4 & 10 & 50 \\
\hline Heavy Load & 4 & 40 & 12.5 \\
\hline
\end{tabular}

表 $7 \quad D M \max$ の係数

Table 7. Coefficients for $D M \max$.

\begin{tabular}{|c|c|c|c|c|}
\hline Coefficient & OCcst & A & k & Tc (hrs) \\
\hline Value & 13 & 100 & 0.003 & 4 \\
\hline
\end{tabular}

表 8 重み係数

Table 8. Weighting coefficients.

\begin{tabular}{|c|c|c|}
\hline Coefficients & $\mathrm{g}$ & $\mathrm{h}\left(=\mathrm{h}_{2}\right)$ \\
\hline Value & $1.0 / 0.0$ & $0.0 / 0.05$ \\
\hline
\end{tabular}


より, $h=0.05$ とした。

〈5.5〉 電カコスト $\boldsymbol{E C}$ の最小化 潜在的な停電リスク $E x \operatorname{COS} T$ および $A c \operatorname{COS} T$ 計算に用いる $i$ 台事故時の負荷 遮断量 $\sum_{j=1}^{i} G_{j}$ は, 需要家が各供給事業者から購入する電力 量ベクトル $x$ の関数であるが , これらの值は, 各供給事業 者から購入する電力量が決まった後確定する值である。特 に, AcCOST の計算は, ExCOST と異なり，計算に使用 する購入電力べクトル $\boldsymbol{x}$ の要素が決まっていないため, $E C$ は微分可能な関数として表現することができない。従って， $E C$ の最小値を探す手法として，本論文では，経済性最重 視の $E P$ を初期値として, 電力購入量調整を各発電機 2 台 の組み合わせごとに行い，EC を小さくする方向の変化に 対して, 最も感度の高い組み合わせを順次選択していく方 法により供給事業者から購入する電力量を決定した。

〈5 6〉 電力購入量変更による効果 各供給事業者から の電力購入量を変更することによる需要家の信頼度向上に ついて考える。

需要家が第 1 ノードに接続している場合について，電気 料金 $E P$ のみを最小化した場合と電カコスト $E C$ を最小化 した場合の軽負荷時，重負荷時の電気料金 $E P$ ，停電に関す るコスト $O C$ および電カコスト $E C$ を表 9 に示す。軽負荷 時には重み係数として $g=1.0, h=0$, 重負荷時には $g=0$, $h=0.05$ を乥れ光れ採用し, $E P$ 最小化時の $E C$ を与える各 供給事業者からの電力購入量を初期値として $E C$ の最小化 を図ると，停電に関するコストが考慮されることにより，重 要負荷の割合が高い低負荷時には ExCOST が小さくなる ように,重要負荷の割合が低い高負荷時には AcCOST が小 さくなるように電力購入量か変化する。表 10 に各供給事業 者から購入する電力の変化量を, 図 8 に軽負荷時と重負荷 時の電力コスト $E C$ と電気料金 $E P$ を，图 9 に $A c C O S T_{1}$ と $E x \operatorname{COS} T$ の変化の樣子を示す。また,$E P$ 最小化,$E C$ 最小化

表 9 電気料金 $E P$, 停電に関するコスト $O C$ と 電力コスト $E C$ (第 1 ノード)

Table 9. Electricity price $(E P)$, outage related cost $(O C)$, and electricity cost $(E C)$ (Node 1).

\begin{tabular}{|c|c|c|c|c|c|}
\hline & \multirow[b]{2}{*}{ EP } & \multicolumn{2}{|c|}{ OC } & \multirow[b]{2}{*}{ EC } \\
\hline & & & $\begin{array}{c}\text { ExCOST } \\
\text { (Weighted) }\end{array}$ & $\begin{array}{l}\text { AcCOST }_{2} \\
\text { (Weighted) }\end{array}$ & \\
\hline \multirow{2}{*}{$\begin{array}{l}\text { EP Min } \\
(¥ / 8 \mathrm{hr})\end{array}$} & LL & 102440 & 112380 & 0 & 214820 \\
\hline & HL & 159433 & 0 & 497164 & 656597 \\
\hline \multirow{2}{*}{$\begin{array}{l}\mathrm{EC} \mathrm{Min} \\
(\neq / 8 \mathrm{hr})\end{array}$} & LL & 110938 & 80546 & 0 & 191485 \\
\hline & HL & 165787 & 0 & 225262 & 391050 \\
\hline
\end{tabular}

LL: Light Load HL: Heavy Load

\section{表 10 電力購入量の変化}

Table 10. Difference of power purchase.

\begin{tabular}{|c|c|c|c|c|c|}
\hline & $\begin{array}{c}\text { PPS1 } \\
(\mathrm{kW})\end{array}$ & $\begin{array}{c}\text { PPS2 } \\
(\mathrm{kW})\end{array}$ & $\begin{array}{c}\text { PPS3 } \\
(\mathrm{kW})\end{array}$ & $\begin{array}{c}\text { PPS4 } \\
(\mathrm{kW})\end{array}$ & $\begin{array}{c}\text { PPS5 } \\
(\mathrm{kW})\end{array}$ \\
\hline LL & 84.9 & 110.5 & 124.4 & -161.1 & -158.7 \\
\hline HL & 115.8 & 81.5 & 45.5 & -78.5 & -164.3 \\
\hline
\end{tabular}

LL: Light Load HL: Heavy Load
時の需要家の電力購入量は付録内の付表 1 , 付表 2 に示す。

軽負荷時では全負荷量に占める重要負荷の割合が高いた め, 僅かな供給支障でも重要負荷の遮断が起こる可能性が 高く, ExCOST が非常に大きくなっており，1 台事故が発 生しても重要負荷の遮断が必要なため, $A c \operatorname{COS} T_{1}$ も重負 荷時の 2 倍以上となっている。重負荷時では, 全負荷量が 軽負荷時の 1.5 倍となっているため, 電力購入料金は大き くなっているが, 重要負荷量は軽負荷時と同樣のため, 光 の割合は小さくなっている。従って，供給支障が小さい場 合には停電による損害も小さいので, $\operatorname{ExCOST}, A c \operatorname{COS} T_{1}$ 共に軽負荷時より大幅に小さい值となっている。

購入電力の変更結果および信頼度向上効果を表 11 に示 す。購入する電力量を変更することによって, 軽負荷時で は EPの $8.3 \%$ の増加に対して OC $(E x C O S T)$ を $28.3 \%$ 改善 することができた。重負荷時では $E P$ の $4.0 \%$ の増加に対し て OC $\left(\mathrm{AcCOST}_{2}\right)$ を 54.7\%改善することができた。〈4·5〉 節でも述べたが，信頼度向上策による費用対効果の高低は 回避された停電による損害額と実際の電力購入費用の増分 との対比の捉え方に依存するので一概には言えないが, 重 要負荷の割合が高い場合よりも需要負荷の割合が低い場合 のほうが, 電力購入量の調整による費用対効果が高くなる ものと予想される。特に今回のように重要負荷が全負荷量

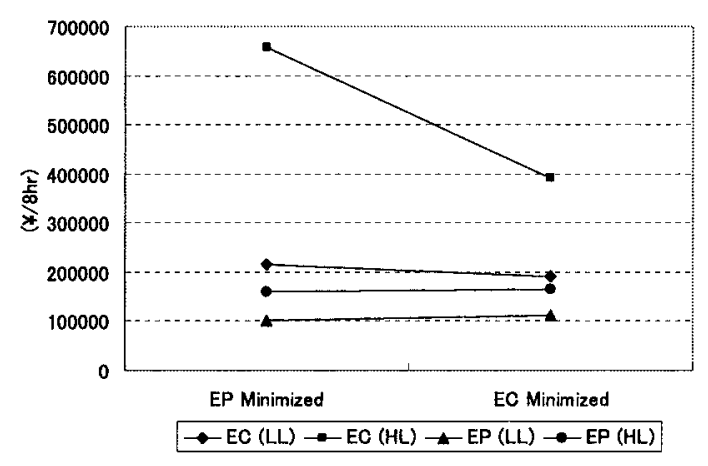

図 8 軽負荷時と重負荷時の電力コスト $E C$ と 電気料金 $E P$

Fig. 8. Electricity cost $(E C)$ and electricity price $(E P)$ for light load (LL) and heavy load (HL).

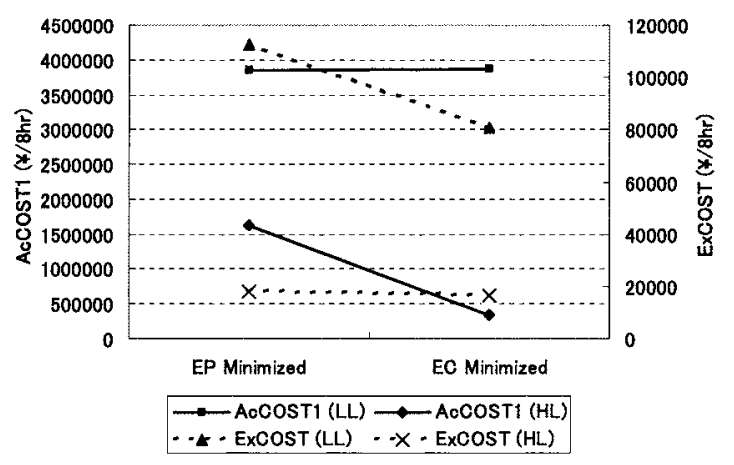

図 9 軽負荷時と重負荷時の $A c C O S T_{1}$ と $E x C O S T$ Fig. 9. $A c C O S T_{1}$ and $\operatorname{ExCOS} T$ for light load $(L L)$ and heavy load $(H L)$. 
表 11 電力購入量変更による効果

Table 11. Effect of power purchase rescheduling.

\begin{tabular}{|c|c|c|c|}
\hline & $\begin{array}{c}\text { EP Increment } \\
(\Psi / 8 \mathrm{hr}) \\
(\%)\end{array}$ & $\begin{array}{c}\text { OC Improvement } \\
(\Psi / 8 \mathrm{hr}) \\
(\%)\end{array}$ & $\begin{array}{c}\text { Cost Effect } \\
(\text { OC Imp) / (EP Inc) }\end{array}$ \\
\hline Light Load & 8498 & 31834 & 3.75 \\
(LL) & 8.3 & 28.3 & 3.41 \\
\hline Heavy Load & 6354 & 271902 & 42.79 \\
(HL) & 4.0 & 54.7 & 13.68 \\
\hline
\end{tabular}

表 12 電気料金 $E P$, 停電に関するコスト $O C$ と 電力コスト $E C$ (第 7 ノード)

Table 12 . Electricity price $(E P)$, outage related cost $(O C)$, and electricity cost (EC) (Node 7).

\begin{tabular}{|c|c|c|c|c|c|}
\hline & \multirow[b]{2}{*}{ EP } & \multicolumn{2}{|c|}{ OC } & \multirow[b]{2}{*}{ EC } \\
\hline & & & $\begin{array}{c}\text { ExCOST } \\
\text { (Weighted) }\end{array}$ & $\begin{array}{l}\text { AcCOST }_{2} \\
\text { (Weighted) }\end{array}$ & \\
\hline \multirow{2}{*}{$\begin{array}{l}\text { EP Min } \\
(¥ / 8 \mathrm{hr})\end{array}$} & LL & 102440 & 133651 & 0 & 236090 \\
\hline & HL & 159433 & $\overline{0}$ & 497164 & 656597 \\
\hline \multirow{2}{*}{$\begin{array}{l}\mathrm{EC} \mathrm{Min} \\
(¥ / 8 \mathrm{hr})\end{array}$} & $\mathrm{LL}$ & 111577 & 95769 & 0 & 207346 \\
\hline & HL & 165787 & 0 & 225262 & 391050 \\
\hline
\end{tabular}

LL: Light Load HL: Heavy Load

の 90\%を占めるような負荷状況では, 電力購入量の調整の 効果は小さくなるものと考えられる。

需要家が第 7 ノードに接続した場合の $E P, O C, E C$ を 表 12 に示す。また， $E P$ 最小化， $E C$ 最小化時の需要家の 電力購入量は付録内の付表 3 , 付表 4 に示す。

需要家が第 7 ノードに接続した場合には，第 11 送電線 の単一事故でも供給支障が発生するため，第 1 ノードに接 続した場合と比較すると，第 11 送電線の事故率の影響を受 けるため,ExCOST が高めとなる。このため, 重要負荷の 割合が高い軽負荷時での $E C$ 最小化時の電力購入量は, 事 故率が低く電気料金が高い供給事業者からの購入が多くな り，電気料金 $E P$ が第 1 ノードに接続した場合より高くな る。一方で, 重要負荷の割合が低い重負荷時は, ExCOST の影響がないため,電力購入量に变化はなかった。

信頼度向上策による効果は軽負荷時，重負荷時共に第 1 ノードに接続している場合と同樣の傾向である。

〈5.7〉 オンサイト電源導入による効果需要家側での 信頼度向上策として, オンサイト電源を導入する場合につ いて考える。需要家は第 7 ノードに接続しており，時間帯 は9〜16 時の場合について検討した。

オンサイト電源は, 出力一定で 24 時間運転するものと し，導入費用は¥ $120000 / \mathrm{kW}$ ，事故率は $0.2 \%$ ，運転費用は 15 円 $/ \mathrm{kWh}$ ，導入容量は $300 \mathrm{~kW}$ とした。減価償却期間を 変化させた場合の電気料金 $E P$ の変化を図 10 に示す。

オンサイト電源の導入により, ExCOST は¥14727， AcCOST2 は¥167420 となり，オンサイト電源による信頼 度向上は, 潜在的な停電リスクおよび想定された事故によ る停電の損害の双方を低減する効果があり，信頼度の向上 を図ることが可能であることがわかる。また，図 10 より， 今回の設定においては, 減価償却期間が 2 年半程度より長 くなると，電力購入量を変更した場合より経済性がよくな

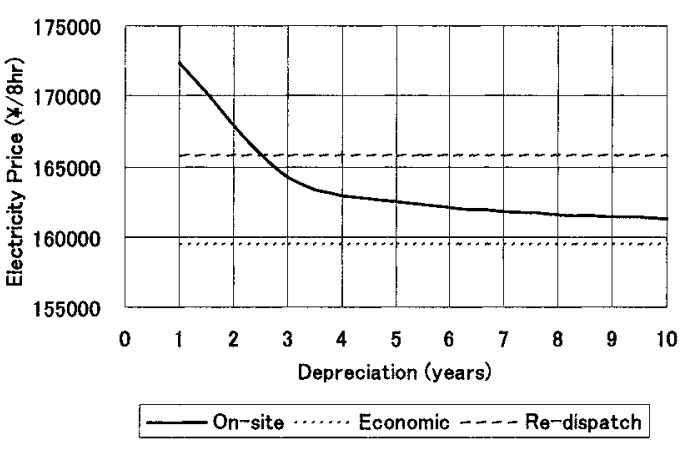

図 10 オンサイト電源導入時の電気料金

Fig. 10. EP curve for onsite generator introduction.

り，10 年程度となると，電気料金は最小値に近い值となり， 経済的かつ信頼度向上にも効果が高いことがわかる。

提案手法は，減価償却期間と費用対効果の関係を捉える ことができるので,オンサイト電源の導入計画にも有効であ ると考えられる。ただし，オンサイト電源導入による信頼 度向上は, 電源の種類, 導入容量や減価償却期間によって, 費用対効果が大きく異なるため，短期的な視点だけでなく 長期的な視点に立った評価も同時に行うことが必要である。

\section{6. まとめ}

本論文では, 需要家が信頼度を考慮した相対契約による 電力購入量を決定する手法を提案した。需要家の電力購入 量決定にあたり，供給事業者の発電設備や流通設備の事故 に起因する潜在的な停電リスクを考慮した，需要家側から 見た相対契約モデルを新たに提案した。更に，潜在的な停 電リスクと想定事故による損害見積から計算される停電に 関わるコストを提案し，需要家側における信頼度評価指標 とした。この指標により，確率的評価と定量的評価を需要 家の負荷構成の特性に従って使い分け, 信頼度評価に需要 家の特性を反映させることが可能となった。

また，需要家側での信頼度向上策と光の費用対効果につ いての評価を行い, 数值計算例を通して回避された停電に よる損害額と電気料金の増分を定量的に示した。この結果 により，提案手法によって信頼度向上策の費用対効果を把 握でき, 提案手法が需要家の信頼度を考慮した電力購入量 決定に有効であることを検証した。

今後の課題として，長期的な視点での経済性と信頼度維 持との協調についての検討や他の市場参加者からの影響を 考慮にいれた信頼度評価が必要であると考えている。また， 信頼度向上策の費用対効果の評価や適切な信頼度水準の議 論に大きな影響を与える需要家の停電コストについての詳 細な調査か望まれるところである。

(平成 16 年 3 月 24 日受付, 平成 16 年 12 月 6 日再受付)

$$
\text { 文献 }
$$

(1) I. Kurihara: "Power system reliability evaluation under the Electricity 
Market”, T. IEE Japan, Vol.120-B, No.7, pp.919-922 (2000-7) (in Japanese) 栗原郁夫 : 「電力自由化のもとでの供給信頼度評価」, 電学論 $\mathrm{B}, \mathbf{1 2 0}$ 7, pp.919-922 (2000-7)

( 2 ) E. Sugihara, H. Kita, J. Hasegawa, and K. Nishiya: "An evaluation of reliability differentiated supply system considering local characteristics", T. IEE Japan, Vol.199-B, No.3, pp.354-361 (1999-3) (in Japanese)

杉原英治・北 裕幸・長谷川淳・西谷健一: 「地域特性を考慮した信頼 度別電力供給方式の導入評価」, 電学論 B, 119, 3, pp.354-361 (1999-3)

( 3 ) C.C. Fong, et al: "Bulk power system reliability-measurement and indices", IEEE Trans. Power Syst., Vol.4, No.3, pp.829-835 (1989)

( 4 ) R.N. Allan, et al: "Bulk power system reliability—predictive indices", IEEE Trans. Power Syst., Vol.5, No.4, pp.1204-1213 (1990)

( 5 ) S. Fockens, A.J.M. van Wijk, and W.C. Turkenburg: "A concise method for calculating expected unserved energy in generating system reliability analysis”, IEEE Trans. Power Syst., Vol.6, No.3, pp.1085-1091 (1991)

( 6 ) M.S. Rios, P.V. Vidal, and D.L. Kiguel: "Bus-based reliability indices and associated costs in the bulk power system", IEEE Trans. Power Syst., Vol.13, No.3, pp.719-724 (1998)

( 7 ) CIGRE WG-37: "Quality of Supply-Customers Requirement”, CIGRE 37116 Report (1999)

（8）横山隆一・陳 洛南，他：電力自由化と技術開発,第 7 章 (陳 洛 南), 東京電機大学出版局 (2001)

(9) R. Allan and R. Billinton: "Probabilistic assessment of power systems", Proc. IEEE, Vol.88, No.2, pp.140-162 (2000)

(10) R. Billinton and P. Wang: "Distribution system reliability cost/worth analysis using analytical and sequential simulation techniques", IEEE Trans. Power Syst., Vol.13, No.4, pp.1245-1250 (1998)

(11) Z. Wang, F. Shokooh, and J. Qiu: "An efficient algorithm for assessing reliability indexes of general distribution systems", IEEE Trans. Power Syst., Vol.17, No.3, pp.608-614 (2002)

(12) L. Goel and R. Billinton: "A procedure for evaluating interrupted energy assessment rates in an overall electric power system", IEEE Trans. Power Syst., Vol.6, No.4, pp.1396-1403 (1991)

(13) P. Wang, R. Billinton, and L. Goel: "Unreliability cost assessment of an electric power system using reliability network equivalent approaches", IEEE Trans. Power Syst., Vol.17, No.3, pp.549-556 (2002)

（14）奈良宏一・佐藤泰司：システム工学の数理手法, 第 4 章, コロナ社 (1996)

(15) K. Nakamura and S. Yamashiro: "A survey study on estimation of customer interruption costs", T. IEE Japan, Vol.199-B, No.2, pp.284-290 (1999-2) (in Japanese)

仲村宏一・山城＼cjkstart迪：「停電コストの推定に関する調査研究」, 電学 論 B, 119, 2, pp.284-290 (1999-2)

(16) "The IEEE Reliability Test System-1996", IEEE Trans. Power Syst., Vol.14, No.3, pp.1010-1020 (1999)

(17) R.N. Allan, R. Billinton, I. Sjarief, L. Goel, and K.S. So: "A reliability test system for educational purposes-basic distribution system data and results", IEEE Trans. Power Syst., Vol.6, No.2, pp.813-820 (1991)

\section{付 録}

需要家が第 1 ノードおよび第 7 ノードに接続した場合の 各供給事業者からの電力購入量と電気料金 $E P, E x \operatorname{COS} T$, $A c \operatorname{COS} T$ を付表 1〜付表 4 に示す。

付表 $1 E P$ 最小化時の結果 (第 1ノード)

app. Table 1. Result of EP minimizing case (Node 1).

\begin{tabular}{|c|c|c|c|c|c|c|}
\hline \multirow{4}{*}{$\begin{array}{l}\text { Light } \\
\text { Load }\end{array}$} & $\begin{array}{c}\mathrm{EP} \\
(\mathrm{z} / 8 \mathrm{hr})\end{array}$ & $\begin{array}{l}\text { PPS1 } \\
(\mathrm{kW})\end{array}$ & $\begin{array}{l}\text { PPS2 } \\
(\mathrm{kW})\end{array}$ & $\begin{array}{l}\text { PPS3 } \\
(\mathrm{kW})\end{array}$ & $\begin{array}{l}\text { PPS4 } \\
(\mathrm{kW})\end{array}$ & $\begin{array}{l}\text { PPS5 } \\
(\mathrm{kW})\end{array}$ \\
\hline & 102440 & 94.02 & 151.43 & 184.69 & 261.19 & 308.67 \\
\hline & $\begin{array}{l}\text { ExCost } \\
(¥ / 8 \mathrm{hr})\end{array}$ & $\begin{array}{l}\text { AcCost1 } \\
\text { (¥/8hr) }\end{array}$ & $\begin{array}{c}\mathrm{AcCost} 2 \\
(¥ / 8 \mathrm{hr})\end{array}$ & $\begin{array}{c}\text { AcCost3 } \\
(¥ / 8 \mathrm{hr})\end{array}$ & $\begin{array}{c}\text { AcCost } 4 \\
(¥ / 8 \mathrm{hr})\end{array}$ & $\begin{array}{c}\text { AcCost5 } \\
\text { ( } ¥ / 8 \mathrm{hr})\end{array}$ \\
\hline & 112380 & 3852088 & 7111824 & 9416782 & 11306593 & 12480000 \\
\hline \multirow{4}{*}{$\begin{array}{r}\text { Heavy } \\
\text { Load }\end{array}$} & $\underset{(\Psi / 8 \mathrm{hr})}{\mathrm{EP}}$ & $\begin{array}{l}\text { PPS1 } \\
(\mathrm{kW})\end{array}$ & $\begin{array}{l}\text { PPS2 } \\
(\mathrm{kW})\end{array}$ & $\begin{array}{l}\text { PPS3 } \\
(\mathrm{kW})\end{array}$ & $\begin{array}{l}\text { PPS4 } \\
\text { (kW) }\end{array}$ & $\begin{array}{l}\text { PPS5 } \\
(\mathrm{kW})\end{array}$ \\
\hline & 159433 & 134.25 & 218.48 & 270.90 & 395.29 & 481.08 \\
\hline & $\begin{array}{l}\text { ExCost } \\
(\Psi / 8 \mathrm{hr})\end{array}$ & $\begin{array}{l}\text { AcCost1 } \\
\text { (¥/8hr) }\end{array}$ & $\begin{array}{c}\text { AcCost2 } \\
(¥ / 8 \mathrm{hr})\end{array}$ & $\begin{array}{c}\text { AcCost3 } \\
(¥ / 8 \mathrm{hr})\end{array}$ & $\begin{array}{l}\text { AcCost4 } \\
\text { ( } ¥ / 8 \mathrm{hr})\end{array}$ & $\begin{array}{c}\text { AcCost5 } \\
\text { (¥/8hr) }\end{array}$ \\
\hline & 17782 & 1625387 & 9943287 & 14169773 & 17015716 & 18709652 \\
\hline
\end{tabular}

付表 $2 E C$ 最小化時の結果 (第 1 ノード)

app. Table 2. Result of $E C$ minimizing case (Node 1).

\begin{tabular}{|c|c|c|c|c|c|c|}
\hline \multirow{4}{*}{$\begin{array}{l}\text { Light } \\
\text { Load }\end{array}$} & $\begin{array}{c}\mathrm{EP} \\
(\Psi / 8 \mathrm{hr})\end{array}$ & $\begin{array}{l}\text { PPS1 } \\
(\mathrm{kW})\end{array}$ & $\begin{array}{l}\text { PPS2 } \\
\text { (kW) }\end{array}$ & $\begin{array}{l}\text { PPS3 } \\
(\mathrm{kW})\end{array}$ & $\begin{array}{l}\text { PPS4 } \\
(\mathrm{kW})\end{array}$ & $\begin{array}{l}\text { PPS5 } \\
\text { (kW) }\end{array}$ \\
\hline & 110938 & 178.9 & 261.9 & 309.1 & 100.1 & 150.0 \\
\hline & $\begin{array}{l}\text { ExCost } \\
(¥ / 8 \mathrm{hr})\end{array}$ & $\begin{array}{c}\text { AcCostl } \\
(¥ / 8 \mathrm{hr})\end{array}$ & $\begin{array}{c}\text { AcCost } 2 \\
(\Psi / 8 \mathrm{hr})\end{array}$ & $\begin{array}{c}\text { AcCost3 } \\
(₹ / 8 \mathrm{hr})\end{array}$ & $\begin{array}{c}\text { AcCost } 4 \\
(\mp / 8 \mathrm{hr})\end{array}$ & $\begin{array}{c}\text { AcCost5 } \\
(¥ / 8 \mathrm{hr})\end{array}$ \\
\hline & 80546 & 3857358 & 7126321 & 9358906 & 11230905 & 12480000 \\
\hline \multirow{4}{*}{$\begin{array}{l}\text { Heavy } \\
\text { Load }\end{array}$} & $\begin{array}{c}\mathrm{EP} \\
(\Psi / 8 \mathrm{hr})\end{array}$ & $\begin{array}{l}\text { PPS1 } \\
(\mathrm{kW})\end{array}$ & $\begin{array}{l}\text { PPS2 } \\
(\mathrm{kW})\end{array}$ & $\begin{array}{l}\text { PPS3 } \\
(\mathrm{kW})\end{array}$ & $\begin{array}{l}\text { PPS4 } \\
(\mathrm{kW})\end{array}$ & $\begin{array}{l}\text { PPS5 } \\
(\mathrm{kW})\end{array}$ \\
\hline & 165787 & 250.0 & 300.0 & 316.4 & 316.8 & 316.8 \\
\hline & $\begin{array}{l}\text { ExCost } \\
(\Psi / 8 \mathrm{hr})\end{array}$ & $\begin{array}{c}\text { AcCost } 1 \\
(¥ / 8 \mathrm{hr})\end{array}$ & $\begin{array}{c}\text { AcCost } 2 \\
(¥ / 8 \mathrm{hr})\end{array}$ & $\begin{array}{c}\text { AcCost3 } \\
(\Psi / 8 \mathrm{hr})\end{array}$ & $\begin{array}{c}\text { AcCost4 } \\
(¥ / 8 \mathrm{hr})\end{array}$ & $\begin{array}{c}\text { AcCost5 } \\
(¥ / 8 \mathrm{hr})\end{array}$ \\
\hline & 16214 & 341407 & 4505243 & 11248530 & 15531625 & 18709652 \\
\hline
\end{tabular}

付表 $3 E P$ 最小化時の結果 (第 7 ノード)

app. Table 3. Result of EP minimizing case (Node 7).

\begin{tabular}{|c|c|c|c|c|c|c|}
\hline \multirow{4}{*}{$\begin{array}{l}\text { Light } \\
\text { Load }\end{array}$} & $\begin{array}{c}\text { EP } \\
(\Psi / 8 \mathrm{hr})\end{array}$ & $\begin{array}{l}\text { PPS1 } \\
(\mathrm{kW})\end{array}$ & $\begin{array}{l}\text { PPS2 } \\
(\mathrm{kW})\end{array}$ & $\begin{array}{l}\text { PPS3 } \\
(\mathrm{kW})\end{array}$ & $\begin{array}{l}\text { PPS4 } \\
(\mathrm{kW})\end{array}$ & $\begin{array}{l}\text { PPS5 } \\
(\mathrm{kW})\end{array}$ \\
\hline & 102440 & 94.02 & 151.43 & 184.69 & 261.19 & 308.67 \\
\hline & $\begin{array}{l}\text { ExCost } \\
\text { (¥/8hr) }\end{array}$ & $\begin{array}{c}\text { AcCost1 } \\
(¥ / 8 \mathrm{hr})\end{array}$ & $\begin{array}{c}\text { AcCost2 } \\
(¥ / 8 \mathrm{hr})\end{array}$ & $\begin{array}{c}\text { AcCost3 } \\
\text { ( } ¥ / 8 \mathrm{hr})\end{array}$ & $\begin{array}{c}\text { AcCost4 } \\
(¥ / 8 \mathrm{hr})\end{array}$ & $\begin{array}{c}\text { AcCost5 } \\
\text { (¥/8hr) }\end{array}$ \\
\hline & 133651 & 3852088 & 7111824 & 9416782 & 11306593 & 12480000 \\
\hline \multirow{4}{*}{$\begin{array}{r}\text { Heavy } \\
\text { Load }\end{array}$} & $\begin{array}{c}\mathrm{EP} \\
(\Psi / 8 \mathrm{hr})\end{array}$ & $\begin{array}{l}\text { PPS1 } \\
(\mathrm{kW})\end{array}$ & $\begin{array}{l}\text { PPS2 } \\
\text { (kW) }\end{array}$ & $\begin{array}{l}\text { PPS3 } \\
(\mathrm{kW})\end{array}$ & $\begin{array}{l}\text { PPS4 } \\
(\mathrm{kW})\end{array}$ & $\begin{array}{l}\text { PPS5 } \\
\text { (kW) }\end{array}$ \\
\hline & 159433 & 134.25 & 218.48 & 270.90 & 395.29 & 481.08 \\
\hline & $\begin{array}{l}\text { ExCost } \\
\text { (¥/8hr) }\end{array}$ & $\begin{array}{c}\text { AcCost1 } \\
(\Psi / 8 \mathrm{hr})\end{array}$ & $\begin{array}{c}\text { AcCost2 } \\
(¥ / 8 \mathrm{hr})\end{array}$ & $\begin{array}{c}\text { AcCost } 3 \\
(¥ / 8 \mathrm{hr})\end{array}$ & $\begin{array}{c}\text { AcCost4 } \\
(\Psi / 8 \mathrm{hr})\end{array}$ & $\begin{array}{c}\text { AcCost5 } \\
(¥ / 8 \mathrm{hr})\end{array}$ \\
\hline & 19314 & 1625387 & 9943287 & 14169773 & 17015716 & 18709652 \\
\hline
\end{tabular}

付表 $4 E C$ 最小化時の結果 (第 7 ノード)

app. Table 4. Result of EC minimizing case (Node 7).

\begin{tabular}{|c|c|c|c|c|c|c|}
\hline \multirow{4}{*}{$\begin{array}{l}\text { Light } \\
\text { Load }\end{array}$} & $\begin{array}{c}\text { EP } \\
(\Psi / 8 \mathrm{hr})\end{array}$ & $\begin{array}{l}\text { PPS1 } \\
(\mathrm{kW})\end{array}$ & $\begin{array}{l}\text { PPS2 } \\
\text { (kW) }\end{array}$ & $\begin{array}{l}\text { PPS3 } \\
(\mathrm{kW})\end{array}$ & $\begin{array}{l}\text { PPS4 } \\
\text { (kW) }\end{array}$ & $\begin{array}{l}\text { PPS5 } \\
(\mathrm{kW})\end{array}$ \\
\hline & 111577 & 197.9 & 281.9 & 270.1 & 100.1 & 150.0 \\
\hline & $\begin{array}{l}\text { ExCost } \\
(\Psi / 8 \mathrm{hr})\end{array}$ & $\begin{array}{c}\text { AcCost } 1 \\
(¥ / 8 \mathrm{hr})\end{array}$ & $\begin{array}{c}\text { AcCost2 } \\
(¥ / 8 \mathrm{hr})\end{array}$ & $\begin{array}{c}\text { AcCost3 } \\
(¥ / 8 \mathrm{hr})\end{array}$ & $\begin{array}{c}\text { AcCost4 } \\
(¥ / 8 \mathrm{hr})\end{array}$ & $\begin{array}{c}\text { AcCost5 } \\
(¥ / 8 \mathrm{hr})\end{array}$ \\
\hline & 95769 & 3518057 & 6889201 & 9358906 & 11230905 & 12480000 \\
\hline \multirow{4}{*}{$\begin{array}{l}\text { Heavy } \\
\text { Load }\end{array}$} & $\begin{array}{c}\mathrm{EP} \\
(\Psi / 8 \mathrm{hr})\end{array}$ & $\begin{array}{l}\text { PPSI } \\
(\mathrm{kW})\end{array}$ & $\begin{array}{l}\text { PPS2 } \\
(\mathrm{kW})\end{array}$ & $\begin{array}{l}\text { PPS3 } \\
(\mathrm{kW})\end{array}$ & $\begin{array}{l}\text { PPS4 } \\
(\mathrm{kW})\end{array}$ & $\begin{array}{l}\text { PPS5 } \\
(\mathrm{kW})\end{array}$ \\
\hline & 165787 & 250.0 & 300.0 & 316.4 & 316.8 & 316.8 \\
\hline & $\begin{array}{l}\text { ExCost } \\
(\Psi / 8 \mathrm{hr})\end{array}$ & $\begin{array}{c}\text { AcCost1 } \\
(\Psi / 8 \mathrm{hr})\end{array}$ & $\begin{array}{c}\text { AcCost2 } \\
(¥ / 8 \mathrm{hr})\end{array}$ & $\begin{array}{c}\text { AcCost3 } \\
(\Psi / 8 \mathrm{hr})\end{array}$ & $\begin{array}{c}\text { AcCost4 } \\
(¥ / 8 \mathrm{hr})\end{array}$ & $\begin{array}{c}\text { AcCost5 } \\
\text { ( } ¥ / 8 \mathrm{hr})\end{array}$ \\
\hline & 16214 & 341407 & 4505243 & 11248530 & 15531625 & 18709652 \\
\hline
\end{tabular}

新 岡

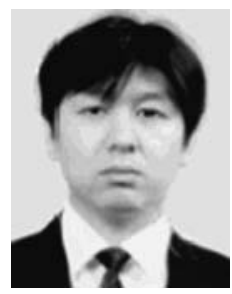

聡 (正員) 1971 年 6 月 24 日生。1995 年早稲田大学 理工学部電気工学科卒業。1998 年法政大学工学 研究科電気工学専攻修士課程修了。2001 年東京 都立大学工学研究科電気工学専攻博士課程修了。 現在三菱総合研究所勤務。電力システムの信頼度 に関する研究に従事。IEEE 会員。

横山 隆 一 (正員) 1944 年 8 月 25 日生。1968 年早稲田大学

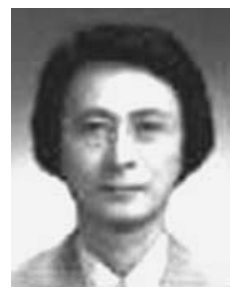
理工学部電気工学科卒業。1970 年同大学工学研 究科電気工学専攻修士課程修了。1973 年同博士課 程修了。工学博士。電力システムの計画・運用・ 制御に関する研究に従事。CIGRE，IEEE，SICE 会員。 